\title{
The Law Enforcement On Phornographic Cases
}

\author{
Nanda Setya Laksana ${ }^{*}$ and Achmad Sulchan ${ }^{* *}$ ) \\ *) Universitas Islam Sultan Agung (UNISSULA) Semarang, E-mail: \\ nandasetyalaksana19@gmail.com \\ **) Faculty of Law Universitas Islam Sultan Agung
}

\begin{abstract}
This study aims to determine the form of law enforcement against pornography in the investigation process as well as to find out the obstacles faced and provide solutions in overcoming the crime of pornography according to Act No. 44 of 2008, and also to find out the judges' considerations in deciding criminal cases of pornography in the Jepara District Court with case number 138/Pid.B/2018/PN.Jpa, and to find out the law enforcement of pornography crimes based on Act No. 44 of 2008 concerning pornography. This research was carried out at the Jepara District Court. To achieve the objectives of the study, the researchers used data collection methods: interview methods, library methods, and data analysis methods related to the discussion being studied. The conclusion of this research isBased on the facts revealed at the trial, the defendant has been proven to have fulfilled all the elements of the article and in the trial there were no things that could abolish the crime, both justifying reasons and excuses, while for the philosophical and sociological aspects, what was considered by the Panel of Judges was because The defendant's actions violated the norms of decency in society. So that the sentence is very appropriate to be handed down to the defendant so that there is a sense of justice in the community.
\end{abstract}

Keywords: Law Enforcement; Crime; Pornography.

\section{Introduction}

The Criminal Code (KUHP) is known as starbaar feit, while the legislators do not provide an explanation of what exactly is meant by the word "strafbaar feit". Adam Chazawi says: Strafbar feit is an act that is prohibited by law accompanied by criminal threats for those who violate the prohibition. ${ }^{1}$ R.Soesilo says: "To mention the term "criminal" and he formulates that what he means by punishment is a feeling of discomfort or misery that is imposed by a judge with a verdict on a person who has violated the criminal law. ${ }^{2}$

In general, the term criminal is often interpreted the same as the term punishment. But in essence there are differences in the use of the term punishment with criminal. Punishment is a general meaning, as a punishment that suffers or sorrow that is deliberately bestowed on someone. While criminal is a special understanding related to criminal law. As a special meaning. But the two terms also have a feeling that is the same as a punishment or suffering.

According to Moeljatno as quoted by Nur Khairul Hasanah's thesis: "Penalties derived from the word "staff" are conventional terms. In this case he does not agree with these terms and uses the conventional term, namely "criminal" to replace the word "staff". Moeljatno further explained that if "staff is defined as

\footnotetext{
${ }^{1}$ Adami Chazawi, 2015, Tindak Pidana Pornografi, Jakarta : Sinar Grafika, p. 1

${ }^{2}$ R. Soesilo. 1996. Kitab Undang - Undang Hukum Pidana (KUHP) Serta Komentar - Komentar Setiap Pasal, Bogor: Pilotea, p. 35
} 
"punishment" then "stafrecht" should be interpreted as "punishment law".3 Andi Hamzah says: "Indonesian legal experts distinguish the term punishment from criminal, which in Dutch is known as "staff". The term punishment is a general term used for all types of sanctions in the realm of civil, administrative, disciplinary and criminal law. While the term criminal is defined narrowly, namely only sanctions related to criminal law. ${ }^{4}$ According to Adam Chazawi: "The crime of pornography showing oneself or another person in a show or in public that depicts nudity, sexual exploitation, intercourse (article 36 jo. 10 of the pornography law".

Article 36 of Act No. 44 of 2008 concerning pornography is as follows: "Everyone who exhibits himself or another person in a show or in public depicting nudity, sexual exploitation, intercourse, or other pornographic content as referred to in Article 10 shall be subject to a maximum imprisonment of 10 (ten) years and/or a maximum fine of IDR . 5,000,000,000.00 (five billion rupiah)". Article 36 of the Pornography Act No. 44 of 2008 concerning pornography refers to the same act in Article 10 of Act No. 44 of 2008 concerning pornography which formulates as follows. "Everyone is prohibited from showing themselves or others in shows or in public that depicts nudity, sexual exploitation, intercourse, or other pornographic content".

The problem of pornography at this time is that it is accessed and appears in various print and electronic media which intentionally shows women's genitals, this has an impact and can influence a person to take unwanted actions, such as sexual harassment, sexual abuse, rape and so on which are currently often occurs in society. So if it is wrong / wrong in understanding it, pornography will certainly damage human life in the present and in the future ${ }^{5}$.

Pornography services are all types of pornographic services provided by individuals or in combination through live shows, cable television, terrestrial television, radio, telephone, internet, and other means of communication as well as newspapers, magazines and other printed materials. ${ }^{6}$

Kartini Kartono says: "Basically, every human being has a sexual instinct, however, if teenagers often consume pornography, it is very likely that it will cause an urge to channel their sexual desires by having sex with the opposite sex which is too early to be done at a young age. Therefore, consuming pornography as a teenager has the potential to encourage irresponsible sexual behavior outside of marriage so that it can lead to pregnancy outside of marriage."7

One example of pornography is a motorcycle club holding a Jepara Max Owner (JEMO) community birthday event. The Jepara max owner (JEMO) community birthday event was held at Kartini beach Jepara on Saturday, April 14 2018, the first session of 3 (three) sexy dancers using a bra (bh) and panties (bikini) covered with beach cloth shaped like a negligee perform the choreo dance (movement together/modern dancer) followed by free style (free movement).

\footnotetext{
${ }^{3}$ Scription of Nur Khairul Hasanah. Perbandingan pengaturan human trafficking ditinjau dari KUHP dan UU No.21 Tahun 2007 tentang tindak pidana perdagangan orang. p. 18

${ }^{4}$ Ibid, p. 18

${ }^{5}$ Adam Chazawi, Ibid, p.11

6Ibid, p. 9

${ }^{7}$ Kartini Kartono. 2008. Patologi Sosial: Kenakalan remaja, Jakarta : Rajawali Pers, p. 9
} 
After an interval of 30 minutes the 3 sexy dancers got into the car taking off the beach cloth in the form of a negligee because it was a request, the second session only wore a bra and panties (bikini) after being on stage the 3 sexy dancers danced splashed with lady wash style as if washing motorbike with free style movement on the stage accompanied by DJ music (disc jockey), a show using a bra (bh) and panties (bikini) was carried out in public for about 30 minutes the situation was very crowded and lively and was attended by the club $\mathrm{N}$ Max motorbikes from various areas of Central Java, the place is open, can be seen by the general public, not adults, including children,Sexy dancer performances by wearing a bra (bh) and panties are a form of erotic dance that seems naked, violating the immoral norms of the Jepara society, namely actions that cause lust for those who see it.

Based on the above background, the purpose of this study is to determine and analyze the law enforcement of pornography in the Jepara District Court.

\section{Research Methods}

Research methods in sociological juridical research which in other words is a type of sociological legal research. The sociological juridical purpose is an approach that looks at the legal reality in society. Data collection techniques in this study were carried out by means of library research and field studies. Data analysis was carried out after the data had been collected, the data obtained from further research was analyzed using qualitative analysis, namely by describing the data and facts produced or in other words, by describing the data with sentences arranged in detail, systematically, and analytically, so that it will be easier to make conclusions from research in the field with an interpretation, evaluation and general knowledge.

\section{Results and Discussion}

\subsection{Law Enforcement of the Crime of Pornography at the Jepara District Court.}

Based on the results of research at the Jepara District Court, there are several cases related to pornography crimes in the last 3 years, including:

Table 3.1

Pornography Cases handled by the Jepara District Court

\begin{tabular}{|c|c|c|c|}
\hline No. & $\begin{array}{l}\text { Case } \\
\text { Number }\end{array}$ & Demand & Decision \\
\hline 1 & $\begin{array}{l}\text { 267/Pid. } \\
\text { B/2017/ } \\
\text { PN Jpa }\end{array}$ & $\begin{array}{l}\text { Sentenced criminal charges } \\
\text { against defendant I SP Bin S } \\
\text { (late) and defendant II S } \\
\text { Binti K with imprisonment } \\
\text { for } 2 \text { (two) months each } \\
\text { reduced as long as the } \\
\text { defendants were in } \\
\text { detention with an order that } \\
\text { the defendants remain }\end{array}$ & $\begin{array}{l}\text { Sentenced criminal charges } \\
\text { against defendant I SP Bin S } \\
\text { (late) and defendant II S } \\
\text { Binti K with imprisonment } \\
\text { for } 1 \text { (one) month and } 15 \\
\text { (fifteen) days respectively. }\end{array}$ \\
\hline
\end{tabular}




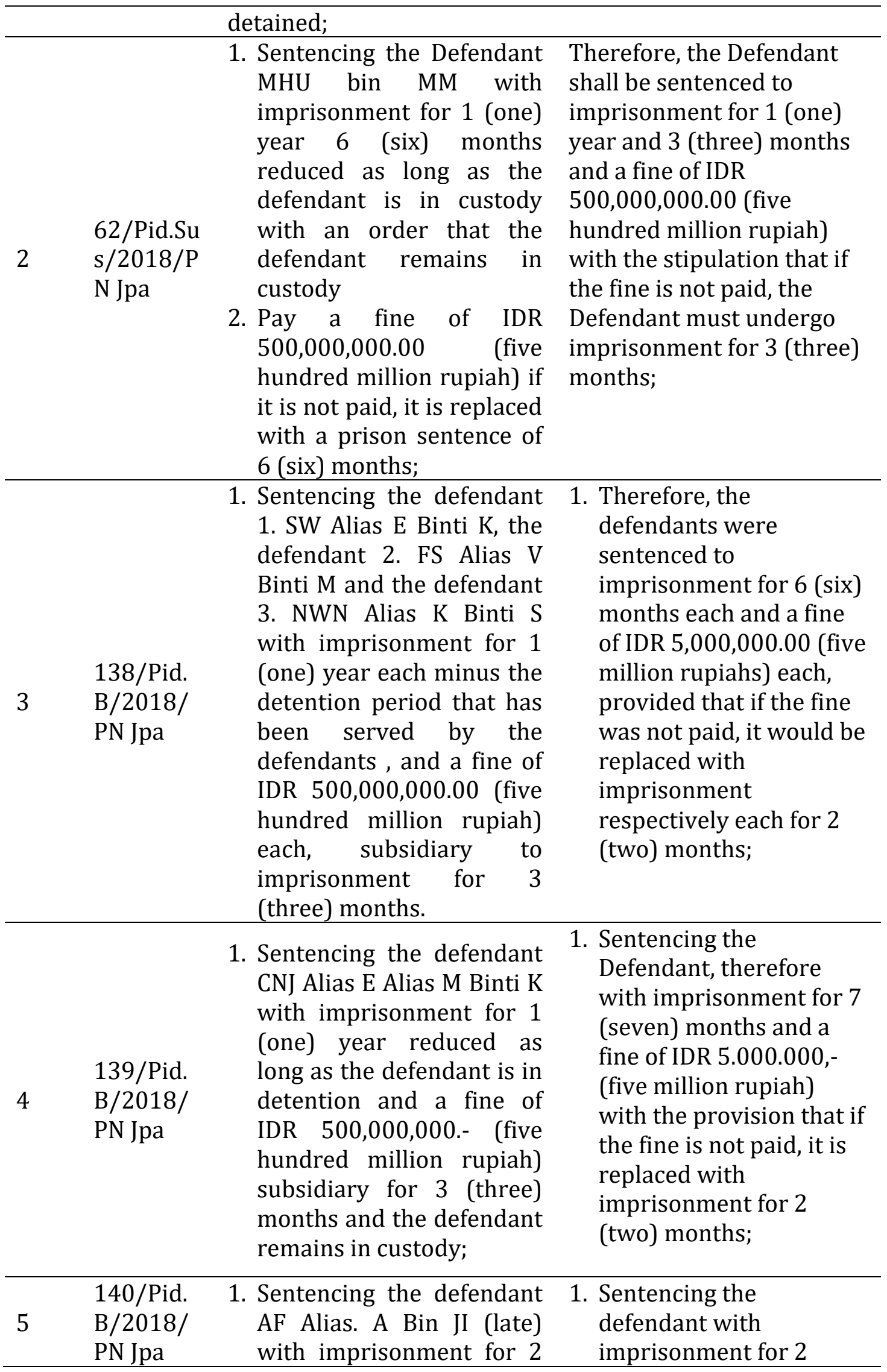




\begin{tabular}{|c|c|c|c|}
\hline & & $\begin{array}{l}\text { (two) years and } 6 \text { (six) } \\
\text { months reduced as long as } \\
\text { the defendant is in } \\
\text { detention and a fine of } \\
\text { IDR } 1,000,000,000,- \text { (one } \\
\text { billion rupiah) Subsidiary } \\
6 \text { (six) months of } \\
\text { confinement. }\end{array}$ & $\begin{array}{l}\text { (two) years and a fine of } \\
\text { IDR } 1,000,000,000 \text {,- (one } \\
\text { billion) provided that if } \\
\text { the fine is not paid, it will } \\
\text { be replaced with } \\
\text { imprisonment for } 3 \\
\text { (three) months; }\end{array}$ \\
\hline 6 & $\begin{array}{l}\text { 141/Pid. } \\
\text { B/2018/ } \\
\text { PN Jpa }\end{array}$ & $\begin{array}{l}\text { Sentencing the defendant } \mathrm{H} \\
\text { Alias. G Bin HN (late) and the } \\
\text { defendant GPH Alias. B Bin S } \\
\text { (late) with imprisonment for } \\
2 \text { (two) years and } 6 \text { (six) } \\
\text { months respectively reduced } \\
\text { for the detention that has } \\
\text { been served by the } \\
\text { defendants and with orders } \\
\text { that the defendants remain } \\
\text { in custody and a fine of IDR } \\
1,000,000,000,- \text { (one billion } \\
\text { rupiah) subsidiary } 6 \text { (six) } \\
\text { months of confinement. }\end{array}$ & $\begin{array}{l}\text { Therefore, the defendants } \\
\text { are sentenced to } \\
\text { imprisonment for } 2 \text { (two) } \\
\text { years each and a fine of IDR } \\
1,000,000,000 \text { (one billion } \\
\text { rupiah) each, provided that } \\
\text { if the fine is not paid, then } \\
\text { the Defendants must each } \\
\text { serve } 3 \text { (three) months in } \\
\text { prison; }\end{array}$ \\
\hline 7 & $\begin{array}{l}\text { 142/Pid. } \\
\text { B/2018/ } \\
\text { PN Jpa }\end{array}$ & $\begin{array}{l}\text { 1. Sentencing the defendant } \\
\text { ES Alias M with } \\
\text { imprisonment for } 2 \text { (two) } \\
\text { years and } 6 \text { (six) months } \\
\text { with an order that the } \\
\text { defendant remains in } \\
\text { custody; } \\
\text { 2. In order for the defendant } \\
\text { to pay a fine of IDR } \\
1,000,000,000 \text { - }^{-} \text {(one } \\
\text { billion rupiah) if it is not } \\
\text { paid, it will be replaced } \\
\text { with a prison sentence of } \\
6 \text { (six) months; }\end{array}$ & $\begin{array}{l}\text { 1. Therefore, the Defendant } \\
\text { is sentenced to } 2 \text { (two) } \\
\text { years in prison and a fine } \\
\text { of IDR } 1,000,000,000 \\
\text { (one billion rupiah) with } \\
\text { the stipulation that if the } \\
\text { fine is not paid, the } \\
\text { Defendant must serve } 3 \\
\text { years imprisonment. } \\
\text { (three months; }\end{array}$ \\
\hline 8 & $\begin{array}{l}\text { 109/Pid. } \\
\text { B/2019 } \\
\text { /PN Jpa }\end{array}$ & $\begin{array}{l}\text { 1. Sentencing the defendant } \\
\text { therefore with a prison } \\
\text { sentence of } 8 \text { (eight) years } \\
\text { deducted while the } \\
\text { defendant is in detention, } \\
\text { with an order that the } \\
\text { defendant remains in } \\
\text { detention with a fine of } \\
\text { IDR 80,000,000,- (eighty }\end{array}$ & $\begin{array}{l}\text { 1. Sentencing the } \\
\text { defendant AS bin S (late) } \\
\text { with imprisonment for } 7 \\
\text { (seven) and a fine of IDR } \\
800,000,000.00 \text { (eight } \\
\text { hundred million rupiah) } \\
\text { with the stipulation that } \\
\text { if the fine is not paid it is } \\
\text { replaced with }\end{array}$ \\
\hline
\end{tabular}




million rupiah) provided
that if it is not paid, it will
be replaced with
imprisonment for 3
(three) months

Source: Jepara District Court

imprisonment for 3

(three) month;

In the table above, it can be seen that during the last 3 (three) years, the Jepara District Court has examined 8 (eight) pornographic cases, all of which have been decided. There are differences in the punishment of each case, the punishment for which is at least 1 (one) month 15 (fifteen) days and a maximum of 8 (eight) years. Differences also occur in criminal fines, a minimum fine of IDR $5,000,000$ (five million rupiah) and a maximum fine of IDR 1,000,000,000 (one billion rupiah). It can be seen that each pornographic crime case has different criminal sanctions and fines. Judging from the results of the verdict above, according to the author, the verdict handed down was very appropriate for the defendants.

\subsection{Judges' Considerations in Enforcing the Law of the Crime of Pornography at the Jepara District Court}

The consequence with the existence of law is that the judge's decision must reflect justice, but the issue of justice will not stop with purely legal considerations, giving birth to justice issues are usually associated with the individual interests of justice seekers, and that means justice according to judges is often interpreted as a victory and defeat. by justice seekers it is abstract, depending on which side we look at it. Therefore, in order to maximize the purpose of the law, we not only fulfill the sense of legal certainty but also fulfill the sense of justice.

Judges' considerations in making decisions must reflect the community's sense of justice. Judges are required to have faith by linking that belief with valid means and evidence as well as creating their own law based on justice which of course does not conflict with Pancasila as the source of all laws.

In the act of a judge's decision requires research, experience and wisdom in order to give birth to a decision that favors the right one. The judge must be sure about the defendant committing a criminal act or not as contained in the elements of the criminal act that he is accused of.

In the theory of legal protection, Article 1 paragraph (3) of the 1945 Constitution states that Indonesia is a state of law, thus the State guarantees the rights of its citizens by providing legal protection for every citizen. The rule of law cannot be separated from the concept of protecting human rights, a state of law without the protection of human rights, a state of law will lose its meaning and legitimacy as a state of law, while the protection of human rights in the absence of a legal state will create tyranny and personal egoism. Protection of human rights is how the state establishes policies to prevent and overcome human rights violations, both intentional and omission. ${ }^{8}$

${ }^{8}$ Andi Pradikta Alvat, Politics Of Law Human Rights Protection In Indonesia, Jurnal Daulat Hukum Vol 2, December 2019. p. 514 
During an interview on Wednesday, December 12 2018, Bayu Agung Kurniawan SH who is a Judge at the Jepara District Court explained that the decision was handed down based on considerations of the charges and demands of the public prosecutor, as well as the facts revealed at trial. Then this matter becomes a consideration for the Panel of Judges to make a decision. In this case, the defendant was found to have violated Article 36 in conjunction with Article 10 of Act No. 44 of 2008 concerning pornography. After that, the Panel of Judges considers the reasons that can be the basis for abolishing the sentence against the defendant, both reasons for forgiveness and reasons for justification. However, in this case, the Panel of Judges did not find a basis to abolish the sentence against the defendant. Therefore, the decision of the panel of judges is lighter than the demands of the Public Prosecutor.

The defendant's mitigating actions include: The defendants behaved politely in the trial, felt guilty, regretted and promised not to repeat their actions; The defendants have never been convicted; The defendants are still young so it is hoped that their behavior will improve in the future.

Judges in deciding criminal cases with decision no. 138/Pid.B/2018/PN Jpa with consideration of aggravating things, namely the defendant's actions were disturbing the community and as a result of the defendant's actions, the victim felt ashamed, while mitigating things were that the defendant had never been convicted, the defendant behaved politely in court, and The defendant felt guilty, regretted his actions and promised not to do it again.

Based on the foregoing matters and accompanied by the facts revealed at the trial, as well as the criminal charges of the public prosecutor and the criminal threat of the offense in question related to the function and purpose of punishment, the Panel of Judges held deliberation and was of the opinion that imprisonment for 6 (six) the month decided is deemed appropriate and in accordance with the sense of justice. The defendant has been proven guilty and the punishment is a retaliation for an act intended to improve the attitude or behavior of the defendant and on the other hand is also intended to prevent others from the possibility of committing a similar act.

\subsection{Constraints and solutions faced by judges in carrying out law enforcement for pornography crimes}

According to Judge Bayu Agung Kurniawan, SH, the first obstacle faced in tackling the problem of pornography is that there is no definition and limitation of pornography itself the fulfillment of all elements of action, especially the element of violating decency which is very dependent on the habits and feelings of the local community 9 .

Solutions that can be given to the prevention of pornography crimes include:

- There is a clear definition and limitation of the Crime of Pornography so that pornographic cases can be brought to the court level where all elements of the act are fulfilled, especially elements that violate moral norms

\footnotetext{
${ }^{9}$ Interview with Mr. Bayu Agung Kurniawan, SH as Judge at the Jepara District Court, Wednesday, December 12, 2018
} 
- Regarding the storage of evidence at the MMC, law enforcers, in this case, the police, are required to be more thorough in examining suspects, so that no more evidence is left behind or lost.

\section{Closing}

The process of law enforcement against perpetrators of non-criminal pornography at the Jepara District Court has been carried out in accordance with the applicable provisions. Law enforcement during the trial is carried out by the judge. The law enforcement process in dealing with a pornographic crime case requires the role of law enforcement the process of handling cases of perpetrators of pornographic crimes is divided into 2, namely: 1 . The process of handling cases before the trial, 2 . the process of handling cases during the trial. Law enforcement efforts are an integral part of crime prevention efforts that provide protection for the community. Legislative steps taken to protect victims from pornography are Act No. 44 of 2008 concerning the eradication of pornography crimes. Suggestions that can be put forward are the need for legal counseling about pornography and for policy makers (Ministry of Health, Health Service, etc.) to make new policies that support preventive efforts against the level of sexual behavior and avoid the occurrence of sexual behavior and avoid deviant sexual behavior, such as For example, include sexual education as early as possible in schools

\section{References}

\section{Journal}

[1] Alvat, Andi Pradikta, 2019. "Politics Of Law Human Rights Protection In Indonesia" dalam Jurnal Daulat Hukum Vol 2, December 2019. url : http://jurnal.unissula.ac.id/index.php/RH/search/search?simpleQuery=uu+ ham\&searchField=query

\section{Books}

[1] Adami Chazawi. 2015. Tindak Pidana Pornografi. Jakarta, Sinar Grafika

[2] Bambang Waluyo, 2002, Penelitian Hukum Dalam Praktek, Jakarta, Sinar Grafika

[3] Kartini Kartono, 2008, Patologi Sosial: Kenakalan remaja, Jakarta : Rajawali Pers

[4] R.Soesilo. 1996. Kitab Undang-Undang Hukum Pidana (KUHP) serta komentar - komentar setiap pasal. Bogor, Politea

[5] Nur Khairul Hasanah. Perbandingan pengaturan human trafficking ditinjau dari KUHP dan UU No.21 Tahun 2007 tentang tindak pidana perdagangan orang, Skripsi

[6] Suharsimi Arikunto. 2002. Prosedur Penelitian Suatu Pendekatan Praktek, Jakarta: Rineka Cipta

\section{Interview}

[1] Interview with Mr. Bayu Agung Kurniawan, SH as Judge at the Jepara District Court, Wednesday, December 12, 2018 